\title{
KCNQ10T1 wt Allele
}

National Cancer Institute

\section{Source}

National Cancer Institute. KCNQ10T1 wt Allele. NCI Thesaurus. Code C114317.

Human KCNQ1OT 1 wild-type allele is located in the vicinity of $11 \mathrm{p} 15$ and is approximately $92 \mathrm{~kb}$ in length. This allele, which encodes KCNQ1 opposite strand/antisense transcript 1 non-coding RNA, is involved in the regulation of gene transcription through epigenetic modification of DNA. Aberrant expression of the gene is associated with BeckwithWiedemann syndrome. 